\title{
Sosialisasi Aplikasi Teknologi Building Information Modelling (BIM) pada Sektor Konstruksi Indonesia
}

Fakhruddin*, H. Parung, M. W. Tjaronge, Rudy Djamaluddin, Rita Irmawaty, A. A. Amiruddin, A. R. Djamaluddin, T. Harianto, A. B. Muhiddin, A. Arsyad, dan St. H. Nur

Departemen Teknik Sipil, Fakultas Teknik Universitas Hasanuddin Fakhrud.civil05@gmail.com*

\begin{abstract}
Abstrak
Building Information Modelling (BIM) adalah sebuah pendekatan untuk desain bangunan, konstruksi, dan manajemen. Software Tekla merupakan revolusi baru dalam bidang rekayasa struktur yang memiliki beberapa keunggulan dibanding program aplikasi lainnya. Tekla Structures merupakan perangkat lunak Building Information Modelling (BIM) yang memungkinkan untuk membuat dan mengelola data secara akurat dan rinci, serta dapat membuat model struktur 3D tanpa melupakan material dan struktur yang kompleks. Penggunaan BIM di Indonesia masih hanya sebatas menjawab persoalan bagaimana mengefisiensikan kebutuhan tenaga kerja, waktu dan uang. Jika kita berkaca pada bagaimana pengaplikasian metode BIM di negara lain, potensi yang dicapai dari pengaplikasian metode BIM di Indonesia masih jauh dari kata maksimal. Tantangan selanjutnya adalah bagaimana mengenalkan teknologi aplikasi BIM ini dan mendorong penerapan BIM ini ke seluruh pihak stakeholder sektor konstruksi yang terkait. Maka dari itu, kegiatan pengabdian pada masyarakat ini bertujuan untuk memberikan pengenalan tentang Building Information Modelling dan memberikan keterampilan dasar dalam penggunaan aplikasi teknologi BIM dengan software Tekla Structures. Kegiatan ini dilaksanakan di Departemen Teknik Sipil, Universitas Hasanuddin yang dihadiri oleh 35 peserta yang berasal dari kalangan praktisi dan akademisi. Tahapan kegiatan pengabdian meliputi kegiatan sosialiasi ke stakeholder melalui mitra Lembaga Pengembangan Jasa Konstruksi Provinsi Sulawesi Selatan (LPJKP Sul-Sel), pengumpulan data berupa shop drawing, pembuatan modul, pemodelan dan laporan berupa quantity dan gambar kerja.
\end{abstract}

Kata Kunci: Building Information Modelling; Tekla Structres; desain bangunan; konstruksi; manajemen.

\section{Pendahuluan}

Salah satu tantangan terbesar sektor konstruksi dalam memasuki Era Revolusi 4.0 adalah kebutuhan pengembangan teknologi pada industri konstruksi secara terus menerus. Kebutuhan teknologi pada industri konstruksi khususnya pada proyek infrastruktur menjadi hal yang tidak dapat dihindarkan mengingat koordinasi antar pihak yang terlibat menjadi suatu keharusan dan saat ini hampir seluruh bidang pekerjaan sudah melakukan otomatisasi dengan penggunaan software termasuk AEC (Architecture, Engineering and Construction).

Pengunaan teknologi komputasi oleh perancang dan praktisi konstruksi sudah umum digunakan di Indonesia, dimana perkembangan teknologi pada konstruksi tumbuh dari bentuk dokumen menjadi visualisasi tiga dimensi, kemudian berkembang dimensi lainnya terhadap biaya, waktu, jadwal, hingga dimensi seterusnya hingga dimensi ke-n (n-D) dan perkembangan inilah menjadi evolusi informasi teknologi yang kemudian disebut Building Information Modelling (BIM).

BIM merupakan salah satu teknologi di bidang AEC yang mampu mensimulasikan informasi berupa representasi digital dari karakteristik fisik dan karakter fungsional dari suatu Bangunan yang di dalamnya terkandung semua Informasi mengenai elemen-elemen Bangunan tersebut yang digunakan sebagai basis pengambilan keputusan dalam kurun waktu siklus umur bangunan mulai dari konsep hingga demolisi, seperti ditunjukkan pada Gambar 1. 


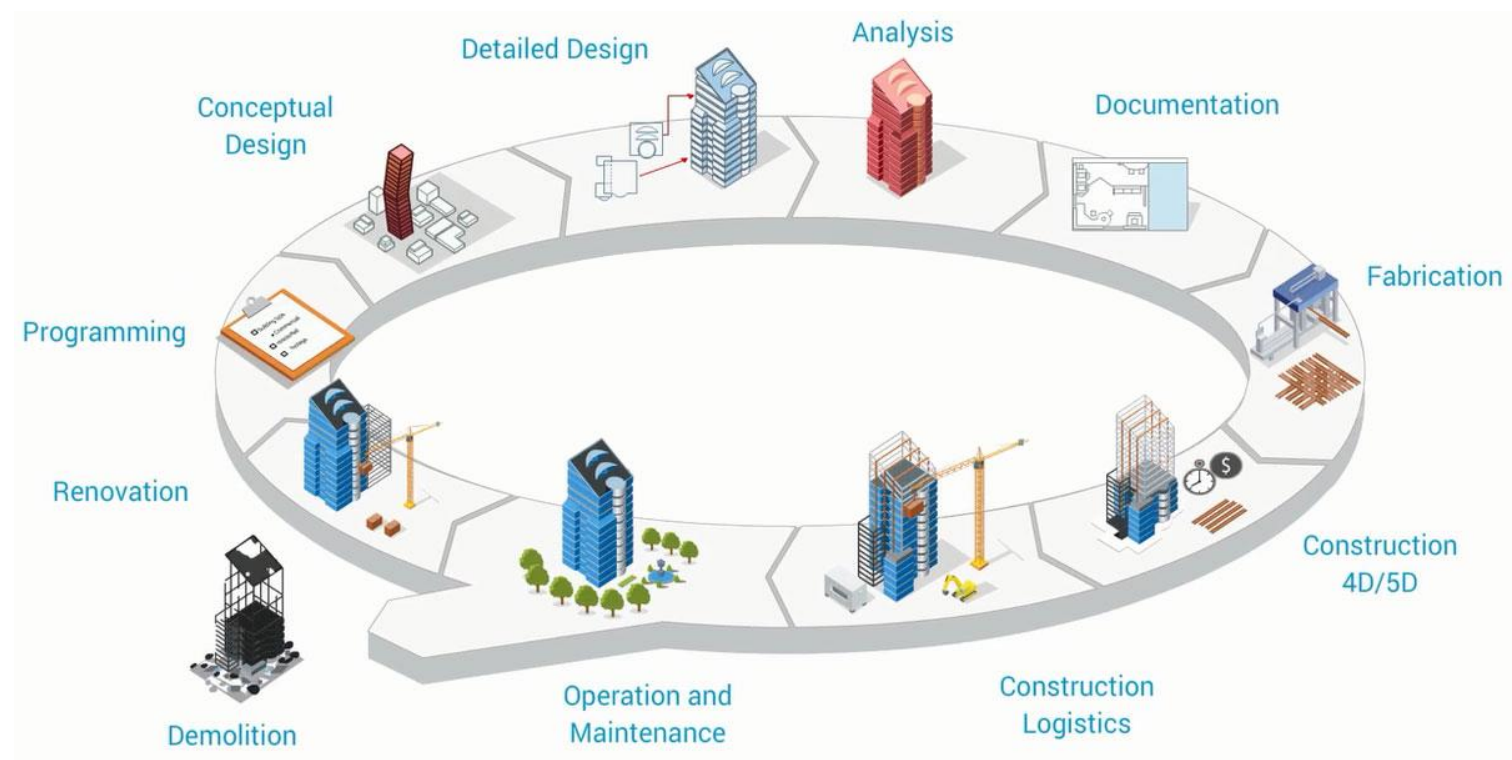

Gambar 1. Siklus Umur pada Proyek

Penerapan Aplikasi Teknologi BIM mulai diterapkan di berbagai sektor sejak tahun 2003 di Amerika Serikat, dan mulai berkembang pesat pada sektor konstruksi sejak tahun 2007. Penerapan BIM mulai diterapkan oleh aktor besar sektor industri konstruksi seperti kontraktor, konsultan, dan developer di Indonesia, tetapi sedikit sekali perusahaan di masing-masing sektor yang menerapkannya. Setelah beberapa tahun BIM diaplikasikan di Indonesia, penggunaannya dirasakan belum maksimal dengan perkembangan yang semakin stagnan.

Seharusnya BIM yang telah diaplikasikan diberbagai sektor tersebut dapat memberikan lesson learned sesuai dengan ekspektasi masing-masing aktor. Namun penggunaan BIM sendiri di Indonesia masih hanya sebatas menjawab persoalan bagaimana mengefisiensikan kebutuhan tenaga kerja, waktu dan uang. Jika kita berkaca pada bagaimana pengaplikasian metode BIM di negara lain, potensi yang dicapai dari pengaplikasian metode BIM di Indonesia masih jauh dari kata maksimal.

Tantangan selanjutnya adalah bagaimana mengenalkan teknologi Aplikasi BIM ini dan mendorong penerapan BIM ini ke seluruh pihak stakeholder sektor konstruksi yang terkait. Maka dari itu, dari hasil sosialisiasi ini, seluruh peserta diharapkan mampu mendapatkan keterampilan dasar dalam pengelolaan software Tekla Structure yang mendukung sistem Building Information Modelling.

Berdasarkan uraian di atas, maka kegiatan ini bertujuan untuk memberikan pengenalan tentang Builiding Information Modelling dan aplikasi di dunia konstruksi saat ini, dan memberikan keterampilan dasar dalam pengolahan aplikasi teknologi BIM dengan software Tekla Structures. 


\section{Latar Belakang Teori}

\subsection{BIM (Building Information Modelling)}

Menurut Eastman et al (2008), BIM merupakan perubahan paradigma yang memiliki banyak manfaat, tidak hanya untuk mereka yang bergerak dalam bidang industri kontruksi bangunan tetapi juga untuk masyarakat yang lebih luas lagi, bangunan yang lebih baik adalah bangunan yang dalam tahap pembangunannya menggunakan energi, tenaga kerja dan modal yang lebih sedikit. BIM pada dasarnya adalah digital platform untuk pembuatan bangunan virtual. Jika BIM diterapkan, modelnya harus dapat berisi semua informasi bangunan tersebut, informasi tersebut digunakan untuk bekerjasama, memprediksi, dan membuat keputusan tentang desain, konstruksi, biaya, dan tahap pemeliharaan bangunan.

BIM merupakan salah satu teknologi di bidang AEC (Architecture, Engineering and Construction) yang mampu mensimulasikan informasi berupa representasi digital dari karakteristik fisik dan fungsional dari suatu bangunan yang di dalamnya terkandung semua Informasi mengenai elemen-elemen bangunan tersebut yang digunakan sebagai basis pengambilan keputusan dalam kurun waktu siklus umur mulai dari konsep hingga demolisi.

Para pengguna merasakan banyak manfaat BIM. Perusahaan yang menggunakan BIM, seperti Skanska dan Barton Malow, merasakan manfaatnya dalam penjadwalan, pembuatan estimasi, dan analisis resiko, proses yang lebih kolaboratif, dan manajemen fasilitas yang lebih baik. BIM juga memberikan peluang untuk mencoba solusi sebelum membangun struktur di lapangan: dengan model yang dapat dibangun, prototipe struktur dapat dibuat secara virtual. Para pihak proyek dapat memahami dan meninjau desain dengan lebih mudah, sehingga terjamin akurasi dan kelengkapannya, serta memberikan visualisasi dan evaluasi alternatif dalam hal biaya dan paramater proyek lainnya. BIM telah diapresiasi dalam meningkatkan komunikasi antar pihak proyek dan kualitas yang secara umum lebih baik.

\subsection{Tekla Structures}

Tekla BIM (Building Information Modelling) merupakan software yang dapat membantu kontraktor untuk mengelola resiko dari biaya-biaya yang tidak terduga dan hilangnya waktu, terutama pada fase pelaksanaan proyek. Software Tekla merupakan revolusi baru dalam bidang rekayasa struktur yang memiliki beberapa keunggulan dibanding program aplikasi lainnya. Tekla BIM (Building Information Modelling) merupakan software yang berbasis ensiklopedi proyek. Software Tekla Structures merupakan perangkat lunak Building Information Modelling (BIM) yang memungkinkan untuk membuat dan mengelola data secara akurat dan rinci, serta dapat membuat model struktur 3D tanpa melupakan material dan struktur yang kompleks. Model Tekla Structures ini dapat mencakup seluruh proses konstruksi bangunan dari konsep desain untuk fabrikasi, erection, dan manajemen konstruksi. 


\section{Metode Pelaksanaan}

\subsection{Waktu dan Pelaksanaan}

Kegiatan ini dilakukan pada bulan April 2019. Lokasi kegiatan di Departemen Teknik Sipil, Fakultas Teknik, Universitas Hasanuddin. Peserta kegiatan sosialisasi Building Information Modelling (BIM) berasal dari perwakilan konsultan dan mahasiswa. Aplikasi yang digunakan adalah Tekla Structure. Dengan adanya mitra kerjasama dalam hal ini Lembaga Pengembangan Jasa Konstruksi Provinsi Sulawesi Selatan (LPJKP Sul-Sel), maka kegiatan sosialisasi aplikasi ini dapat memberikan manfaat dan meningkatkan kapasitas penyedia jasa konstruksi di Indonesia, khususnya di Sulawesi Selatan.

Kegiatan ini dilaksanakan di Seminar Room Departemen Teknik Sipil, Unhas dengan mengundang instruktur ahli yang telah berlisensi resmi untuk memberikan arahan dan bimbingan terkait penggunaan aplikasi ini. Selain itu, instruktur juga dibantu oleh 2 orang dosen Departemen Teknik Sipil Unhas yang juga telah menggunakan dan mendapatkan lisensi dari aplikasi Tekla Structures. Setiap peserta diwajibkan untuk membawa komputer yang kompatibel serta melakukan penginstalan software juga aplikasi lain yang akan mendukung jalannya program Tekla Structures. Peserta dari sosialisasi ini mendapatkan sertifikat dan pemahaman dasar tentang penggunaan Tekla Structures.

\subsection{Alat dan Bahan}

\subsubsection{Alat}
a. Laptop dengan Operating System Windows 7 64-bit, RAM minimal 4 GB
b. Mouse
c. Flash disk

\subsubsection{Bahan}
a. Software Tekla Structures
b. Shop drawing
c. Modul

\subsection{Prosedur Kegiatan}

a. Persiapan

Pekerjaan persiapan meliputi kegiatan sosialisasi ke stakeholder. Mitra yang dipilih adalah LPJKP Sul-Sel sehingga memudahkan dalam sosialisasi ke anggota LPJKP Sul-Sel. Sosialisasi juga dilakukan di kalangan mahasiswa Departement Teknik Sipil, Unhas.

b. Pengumpulan data

Data yang dibutuhkan adalan shop drawing. Data shop drawing tersebut diperoleh dalam bentuk hardcopy dan softcopy file AutoCad (.dwg) dan data schedule dalam bentuk hardcopy. 
c. Pembuatan Modul

Modul yang dibuat terdiri atas metode pengistalan dan metodel pemodelan. Pembuatan modul menggunakan contoh kasus dari shop drawing.

d. Pemodelan

Sebelum pemodelan, peserta melakukan penginstalan. Selanjutnya atas arahan dari instuktur, peserta akan melakukan pemodelan. Pemodelan dimulai dari pembuatan grid dan dilanjutkan ke bagian-bagian struktur dimulai dari pondasi, balok, kolom dan sistem sambungan.

e. Laporan

Laporan berupa quantity dan gambar kerja (drawing).

Diagram alir kegiatan pengabdian ditunjukkan pada Gambar 2.

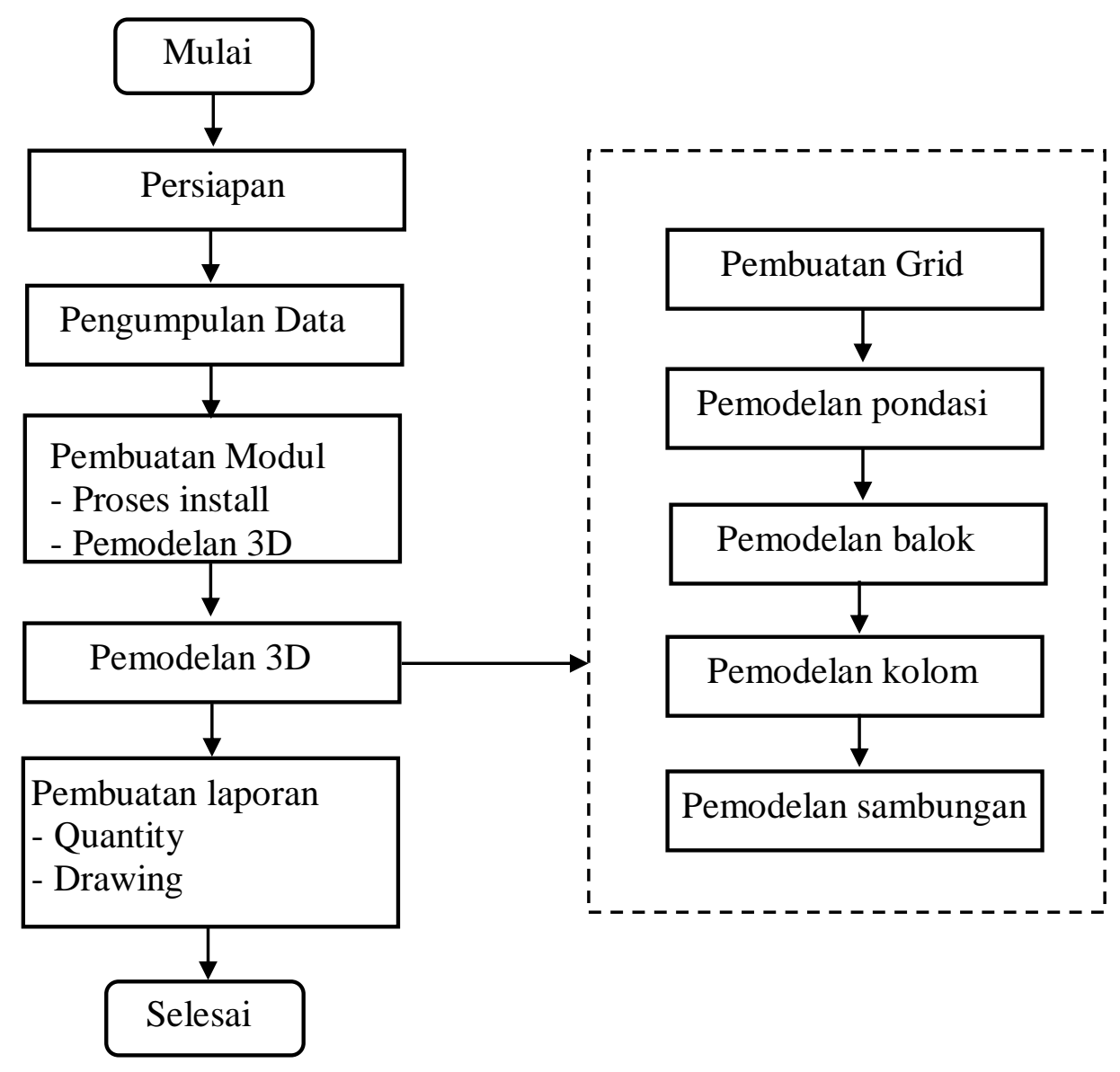

Gambar 2. Diagram Alir Kegiatan Pelatihan BIM

\section{Hasil dan Diskusi}

Kegiatan pengabadian pada masyarakat dengan kegiatan Sosialisasi dan Pelatihan Building Information Modelling dengan Tekla Structures telah dilakukan pada Selasa-Jumat, 24-26 April 
2019. Pelatihan ini dihadiri oleh 35 orang peserta. Kegiatan pelatihan meliputi kegiatan pembuatan modul ajar berupa metode registrasi dan penginstalan seperti ditunjukkan pada Gambar 3.

\section{www.campus.tekla.com, klik register here}

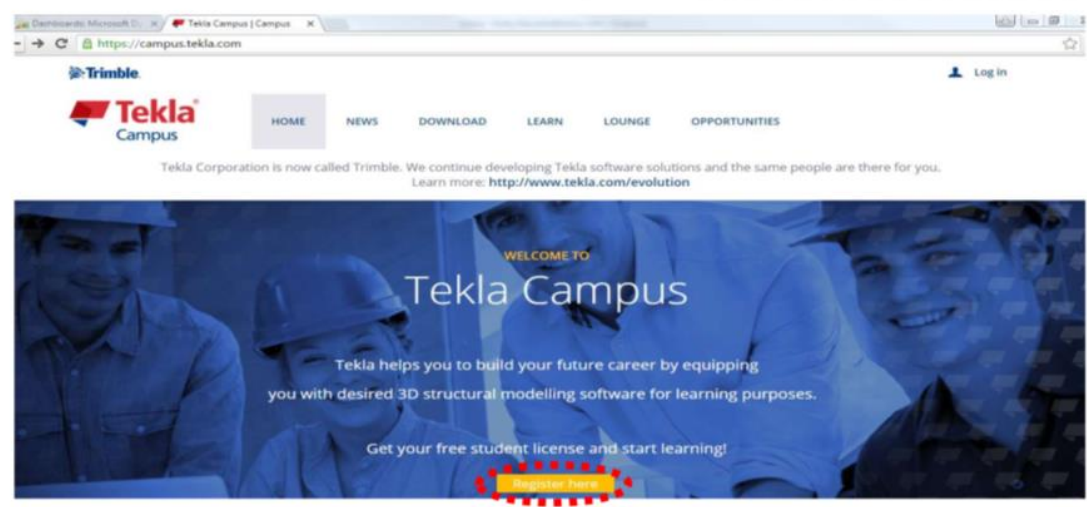

Gambar 34.Modul registrasi dan penginstalan Tekla Structures

Selain itu, kegiatan ini meliputi kegiatan pembuatan modul pelatihan dengan dua contoh kasus seperti ditunjukkan pada Gambar 4 dan 5.

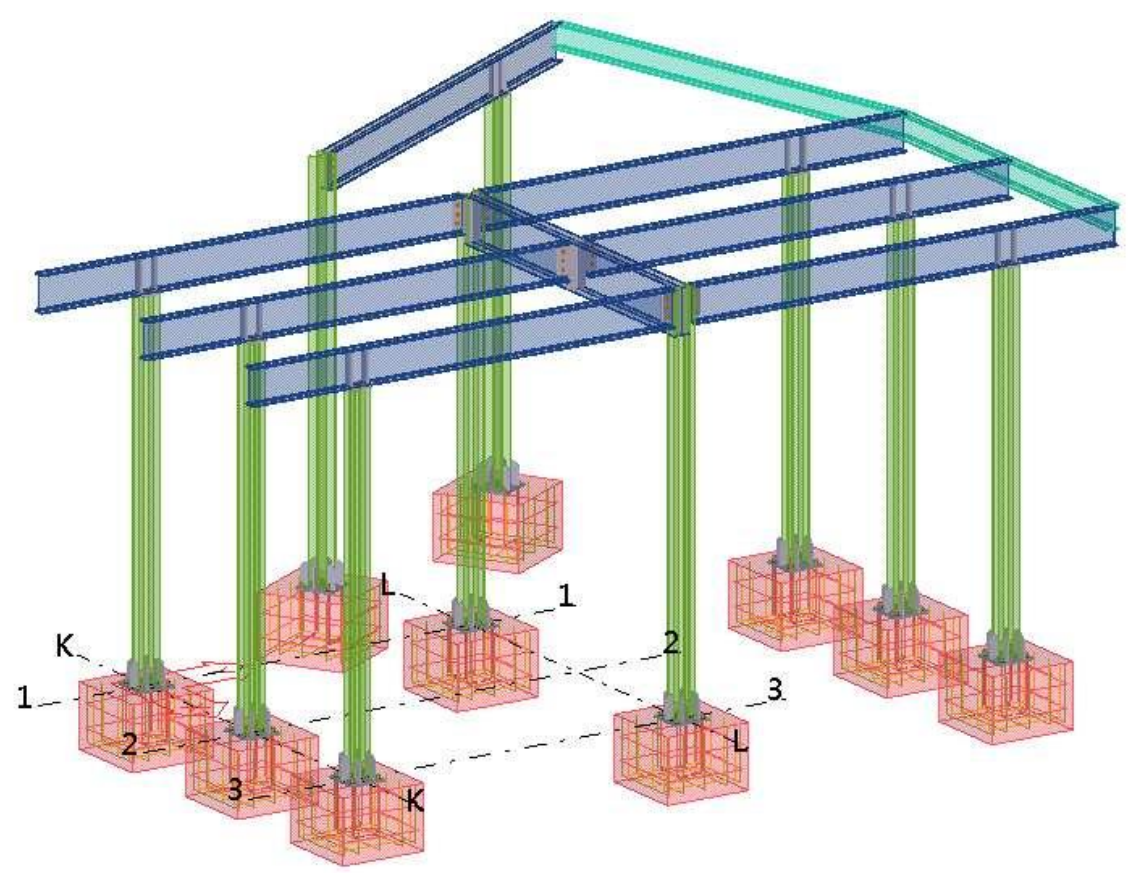

Gambar 4 Pemodelan dengan Tekla Structures (Kasus 1) 


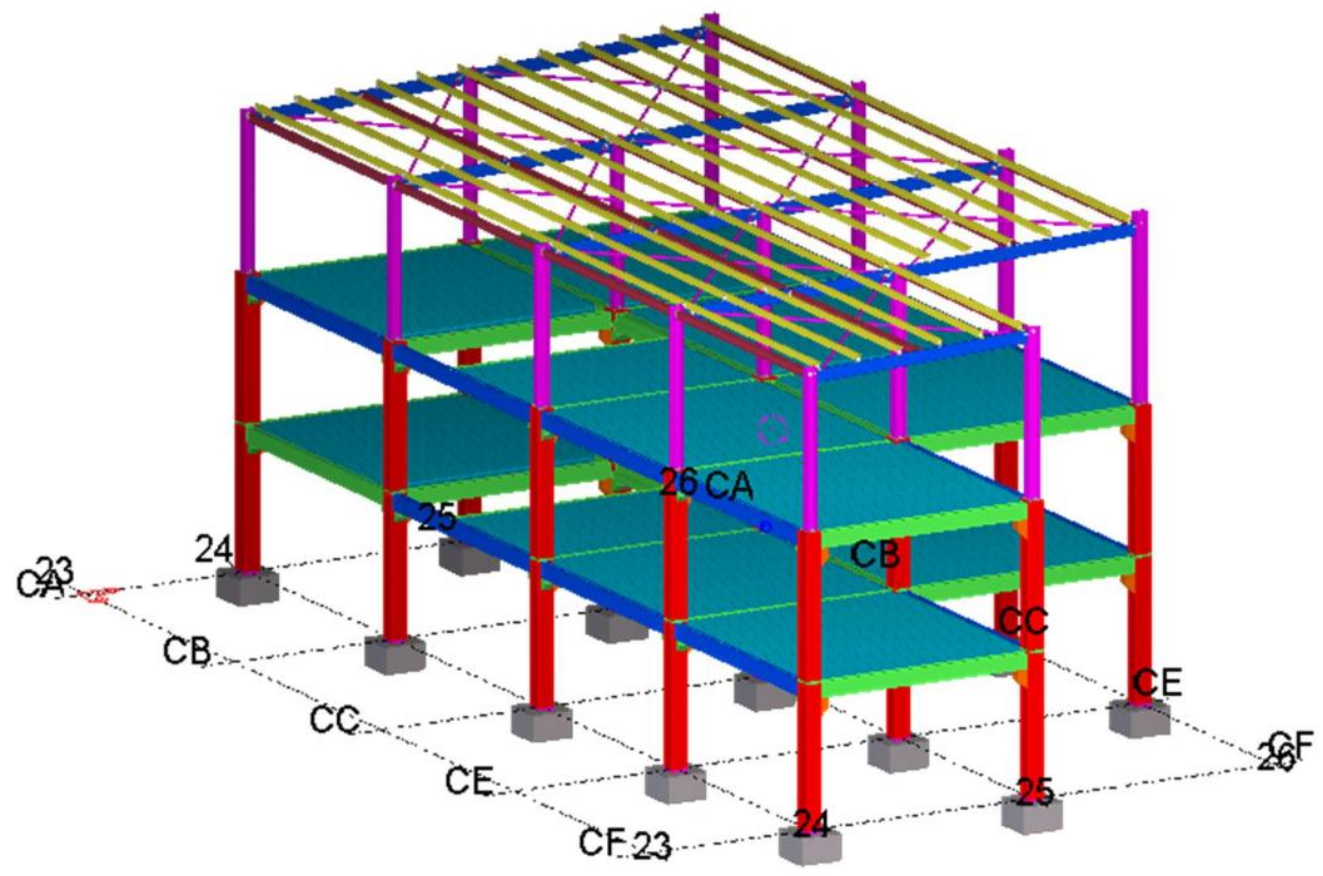

Gambar 5. Pemodelan dengan Tekla Structures (Kasus 2)

Dokumentasi kegiatan pelatihan diperlihatkan pada Gambar 6.

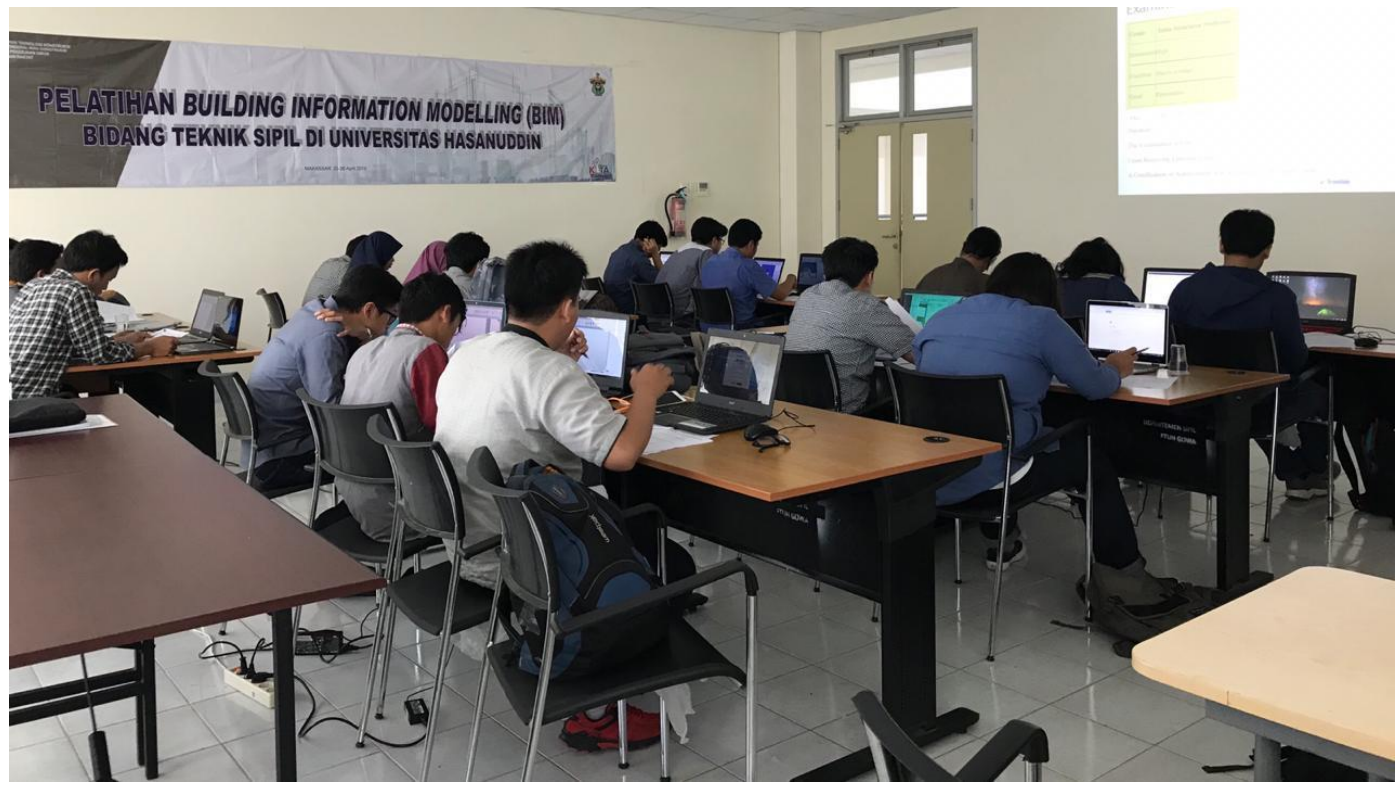




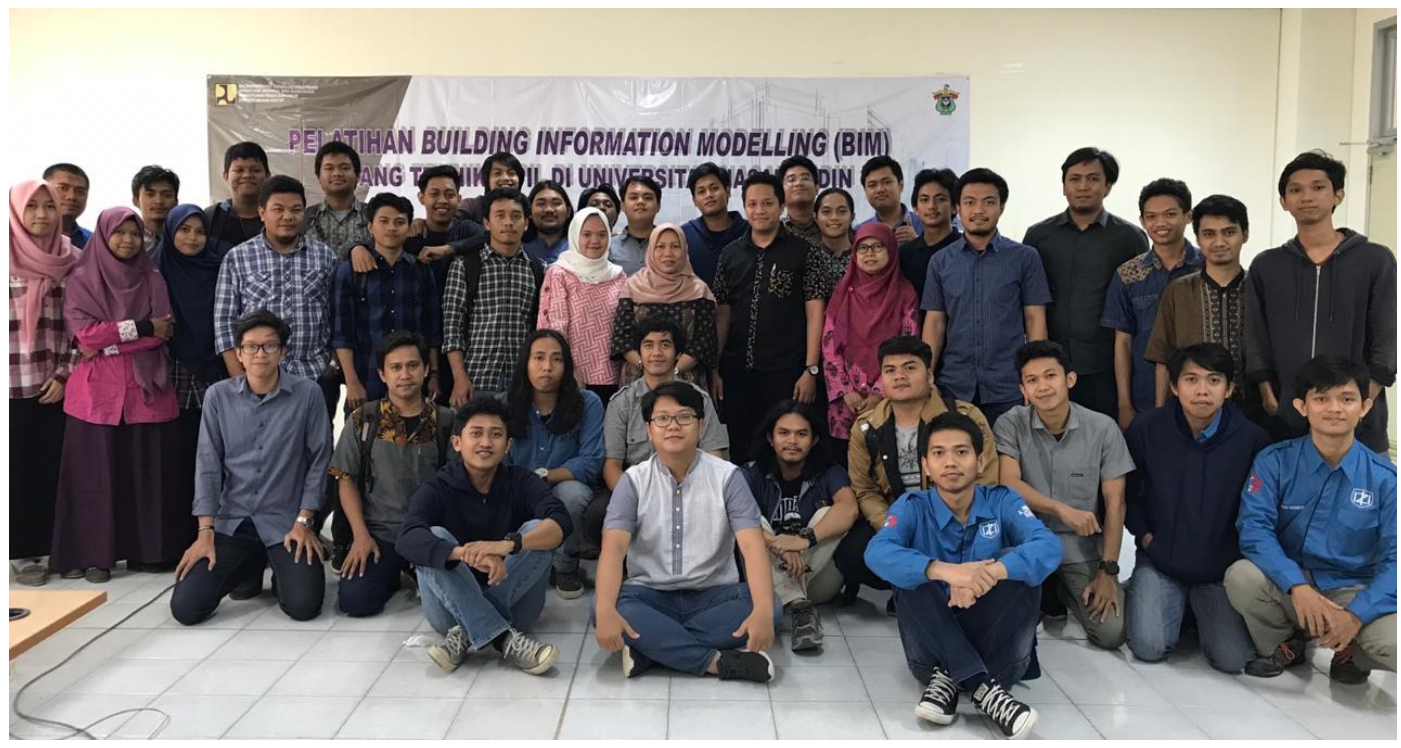

Gambar 6. Dokumentasi kegiatan

\section{Kesimpulan}

Kegiatan Pengabdian kepada Masyarakat telah dilakukan oleh tim pengabdian dari Departemen Teknik Sipil dalam bentuk sosialisasi dan pelatihan Building Information Modelling dengan Tekla Structures di seminar room Departemen Teknik Sipil, Universitas Hasanuddin yang dihadiri oleh 35 peserta. kegiatan ini telah memberikan pengenalan tentang Building Information Modelling (BIM) dan memberikan keterampilan dasar dalam penggunaan aplikasi teknologi BIM khususnya menggunakan aplikasi Tekla Structures.

\section{Ucapan Terima Kasih}

Ucapan terima kasih kepada mitra Lembaga Pengembangan Jasa Konstruksi Provinsi Sulawesi Selatan (LPJKP Sul-Sel) atas kerjasamanya dalam pelaksanaan kegiatan pengabdian ini. Selain itu, penulis juga mengucapkan terima kasih kepada Fakultas Teknik Universitas Universitas Hasanuddin yang telah memberikan pembiayaan.

\section{Daftar Pustaka}

BIM Handbook: A Guide to Building Information Modelling For Owners, Managers, Designers, Engineers, and Contractors. Kanada: John Wiley \& Sons.

Eastman Et Al. (2008). Concept Of BIM. Di dalam skripsi : Janni Tjell (Ed). Building Information Modelling (BIM) In Design Detailing With Focus On Interior Wall Systems, 2010. Denmark: 1-2.

Trimble. (2018). Tecla Structures Fundamental Courses. 